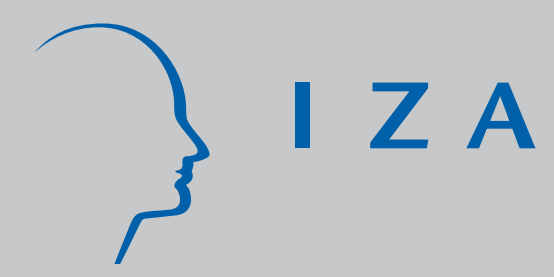

IZA DP No. 776

Determinants of Profit Sharing in the Finnish Corporate Sector

Laura Arranz-Aperte Almas Heshmati

May 2003 


\title{
Determinants of Profit Sharing in the Finnish Corporate Sector
}

\author{
Laura Arranz-Aperte \\ Swedish School of Economics \\ and Business Administration
}

\author{
Almas Heshmati \\ United Nations University and IZA Bonn
}

\author{
Discussion Paper No. 776 \\ May 2003
}

\author{
IZA \\ P.O. Box 7240 \\ D-53072 Bonn \\ Germany \\ Tel.: +49-228-3894-0 \\ Fax: +49-228-3894-210 \\ Email: iza@iza.org
}

\begin{abstract}
This Discussion Paper is issued within the framework of IZA's research area Internationalization of Labor Markets. Any opinions expressed here are those of the author(s) and not those of the institute. Research disseminated by IZA may include views on policy, but the institute itself takes no institutional policy positions.

The Institute for the Study of Labor (IZA) in Bonn is a local and virtual international research center and a place of communication between science, politics and business. IZA is an independent, nonprofit limited liability company (Gesellschaft mit beschränkter Haftung) supported by the Deutsche Post AG. The center is associated with the University of Bonn and offers a stimulating research environment through its research networks, research support, and visitors and doctoral programs. IZA engages in (i) original and internationally competitive research in all fields of labor economics, (ii) development of policy concepts, and (iii) dissemination of research results and concepts to the interested public. The current research program deals with (1) mobility and flexibility of labor, (2) internationalization of labor markets, (3) welfare state and labor market, (4) labor markets in transition countries, (5) the future of labor, (6) evaluation of labor market policies and projects and (7) general labor economics.
\end{abstract}

IZA Discussion Papers often represent preliminary work and are circulated to encourage discussion. Citation of such a paper should account for its provisional character. A revised version may be available on the IZA website (www.iza.org) or directly from the author. 
IZA Discussion Paper No. 776

May 2003

\section{ABSTRACT}

\section{Determinants of Profit Sharing in the Finnish Corporate Sector*}

This study investigates the role of factors that determine individual employees' and firms' participation in profit sharing schemes. Using a large panel data of Finnish employees for the period 1996-2000 we analyse individual and workplace characteristics that make firms employ profit sharing schemes and workers susceptible of receiving profit sharing bonuses. In particular two links between profit sharing schemes and workers performance have been analysed. First, in looking at profit sharing as an incentive device the results show a positive link between firm size and monitoring costs. Second, we find that younger individuals with higher mean salary and capacity to bear risk are more susceptible to profit sharing schemes. The industrial sector in which the individual is employed is also an important determinant factor.

JEL Classification: $\quad \mathrm{C} 23, \mathrm{E} 24, \mathrm{~J} 30, \mathrm{~J} 41$

Keywords: individual, firm, profit sharing, panel data

Corresponding author:

Almas Heshmati

UNU/WIDER

United Nations University

Katajanokanlaituri 6B

00160 Helsinki

Finland

Tel.: +358 961599212

Fax: +385961599333

Email: Almas.Heshmati@wider.unu.edu

\footnotetext{
${ }^{*}$ We are very grateful to Adam Swallow for his careful reading and detailed comments on an earlier version of the manuscript.
} 


\section{INTRODUCTION}

Firms use different payment schemes as incentive devices to influence the attitude, behaviour and productive performance of their employees. The use of different compensation structures should reflect the needs and instruments available to firms as they attempt to maximise profit (see Lazear 1995). The decision to introduce profit sharing will depend on how difficult it is to monitor and measure worker activity, the importance of side activities outside the production itself (innovation, cooperation between workers, etc.), moral hazard considerations and the influence of the worker on the firm's production decisions. Here profit sharing refers to a method of payment where the wages and salaries are composed of two parts, one basic wage and another which is based on the performance of individuals, groups of employees or alternatively a flat rate applied to all employees in a firm. Firm and industry level characteristics (such as how many firms in that particular industry share profits, productivity and profitability of the firm, etc.) are also important factors contributing to the applications of profit sharing and their effectiveness.

Legislation and collective agreements are among the factors that also play an important role in terms of wage setting and payment practices. In industrialised countries most labour force is unionised with various degrees of (de)centralisation in the wage setting and wage bargaining systems. Decentralisation in the wage setting process, as is the case for example in the USA, allows greater wage differentials and more freedom for actions by both parties in bargaining at the local level. In other countries, like Finland, collective agreements severely limit the freedom of the labour market parties to deviate from what is agreed on at the national level. However, even in these countries the recent years of deregulation has shifted decision making to the lower levels. In the current system a number of flexible measures are introduced where not everything is decided by collective agreements. For instance, in the 1990s it became rather common in Finland that local agreements, whose conditions deviate from what is the standard, have been signed.

Profit sharing programmes exist in a wide variety of forms with different types of bonuses and different criteria for when the bonuses are to be paid. The programmes differ both between countries and within countries. Profit sharing programmes involve a 
special type of payment scheme as it makes pay dependent on collective performance. Profit sharing in general is paid to all or most employees in a firm or establishment. Employee shareholding schemes are included only if the share allocation can be regarded as profit sharing bonuses. Firms that use profit sharing usually set a priori a schedule of incentive payments based not only on individual performance, but also on some measure of collective performance such as the profitability of the firm or some unit of it. Profit sharing is used both in countries where firms and workers have more flexibility to agree on individual compensations and in countries where the economy is heavily regulated (OECD 1995).

It has been widely shown that more productive firms tend to have a higher propensity to share profits with their workers. The issue of profit sharing and its effects on productivity of firms has been analysed by Cahuc and Dormont (1997) and Fitzroy and Kraft (1987). ${ }^{1}$ Meyersson-Milgrom et al. (2000) measured and analysed payment, risk and their effects on productivity in Finland. Margolis and Salvanes (2001) also considered alternative hypothesis, that firms share product market rents with their workers in form of higher wages, using Norwegian and French data. However, the effectiveness of profit sharing depends on firms and workers specific characteristics. ${ }^{2}$ For instance, time rates defined as lump sum hourly payments, might be preferred by firms as profit sharing might have adverse effects of providing incentives to direct efforts to activities that provide immediate benefits, obviating the long run perspective. In addition, risk averse workers might prefer time rates to avoid the risk involved in profit sharing. Therefore it is an empirically challenging issue to analyse for which category of individuals in the organisation profit sharing can be considered the most optimal method of payment.

In this paper by using a matched employer-employee dataset on Finnish industries for

\footnotetext{
${ }^{1}$ See also Prendergast (1999) for a survey on the subject.

${ }^{2}$ There is a growing literature on the relationship between flexible workplace practices and productivity of labour. This literature differs from that of profit sharing and is concerned with the determinants of the implementation of innovative human resource practices, so-called High Performance Workplace Systems (HPWS), and their effects on firms performance. HPWS is defined as a decentralization index derived from several indicators using principal component analysis. Bauer (2003) using German data finds that HPWS affect labour productivity (defined as sales per worker) positively, increasing over time, but its positive and small impact on labour efficiency (defined as the inverse of unit labour cost) occurs only in the long run.
} 
the years 1996-2000, we try to explore the following questions: Which factors are the key determinants of profit sharing at individual level? Are there common individual characteristics among workers who participate in various profit sharing schemes? Can profit sharing schemes be explained by certain characteristics from the industrial sector in which the firms operate? Does profit sharing affect the productivity of employees and profits of firms?

Having stated the objectives of this study it is to be noted that the main contribution of this study in relation to the existing literature on profit sharing is related to the use of individual employee data. Analysis of profit sharing at firm level, as is the custom, might be biased. The degree of bias will depend on the distribution of within and between firm's heterogeneity. Bias emerges because individual heterogeneity is neglected in firm-level studies. This bias might result on an overestimation of the impact of profit sharing on firm level outcomes, like productivity or profitability. Despite the fact that individual heterogeneity is the key variable in performance based payment methods, such studies are found to be rare due to either lack of data or the confidential nature of such data. The use of a linked employer-employee dataset including individual characteristics might reduce this bias and result on more accurate results on the impacts of profit sharing on performance.

The rest of the paper is organised as follows. In section 2 the theoretical background of profit sharing is discussed. The Finnish labour market is characterised in Section 3. The data and variable definitions are described in Section 4. The empirical formulation of the model is outlined in section 5 and estimation procedures are discussed. Empirical results are presented in Section 6. Section 7 concludes.

\section{THEORETICAL BACKGROUND}

Firms use different payment schemes as incentive devices to influence the attitude, behaviour and productivity of their employees. However, the instruments that the management of a firm uses to influence the employees are different when the objective is to increase production to a certain level, to obtain a certain degree of quality or to introduce innovations or efficiency-increasing improvements in the production process. The use of different types of payments may also reflect the fact that not every incentive 
mechanism is always applicable or optimal to every case. Firms and individuals are heterogeneous and operate differently in different environments with different products; production processes and not least objects. This heterogeneity in different dimensions results in differences in types, optimality and outcomes of profit sharing.

With reference to the presence of a heterogeneity factor, one example is piece rate schemes that can be used to encourage a single worker to work harder. However, this method can only be implemented when an individual worker's production is perfectly observable to the managers. The use of different compensation structures should reflect the needs of firms for necessary adjustments and measures undertaken to maximise their profit.

Holmström and Milgrom (1991) stress the fact that incentive contracts induce workers to exert higher levels of effort, but at the same time expose them to risk because perfect measures of behaviour and outcomes are hardly ever achievable. Accordingly the optimal intensity of incentives will be given by the expression:

$$
\beta=P^{\prime}(e) /\left[1+r V C^{\prime \prime}(e)\right]
$$

where $P^{\prime}(e)$ denotes the sensitivity of firm's profits to individual's effort, $r$ is the risk aversion coefficient, $V$ is the variance of the random outcome and $C^{\prime \prime}(e)$ denotes the inverse of the responsiveness of effort to incentives. This model can be extended to study how firms use effort and risk outcomes to decide among various methods of payment.

In our setting the firm chooses for among three methods of payment: time rates (denoted by $S$ ), piece rates $(P)$, and a subjective performance measure $(M)$ like profit sharing schemes. ${ }^{3}$ In this generalisation, there are three different optimal intensity of incentives, $\beta_{j}$, all of them lying within the $(0,1)$ interval. The relative importance of each of these methods will depend on individual characteristics (how difficult it is to monitor worker performance, how sensitive individual output is to worker ability, and free-riding considerations) as well as firms and institutional considerations (firm size, firm profits, impact of collective agreements and trade unions, etc). Here we will focus on the relationship between monitoring and pay. In Brown (1990), setting the expected

\footnotetext{
${ }^{3}$ For discussion of firm's choice of method of pay see Brown (1990).
} 
wage offered to a worker is a linear function of its quality $q$ :

$$
W_{j}=\alpha_{j}+\beta_{j} q_{j} \quad \text { for } \mathrm{j}=1,2,3 \text { (method of pay). }
$$

The statistical discrimination literature shows that the relationship between expected wage and worker quality will be steeper ( $\beta_{j}$ larger) the more accurate the available productivity indicator. If all three monitoring intensities are used, and $\beta_{1}<\beta_{2}<\beta_{3}$, it must be that $\alpha_{1}>\alpha_{2}>\alpha_{3}$. Since the cost of monitoring workers is presumably lower the less accurate is the monitoring strategy. Differences in monitoring reflect the different ranking of $\alpha^{\prime}$ s. If monitoring costs in option $j$ are very high, then $\alpha_{j}$ will be very close to zero, and the amount paid with this compensation device can be disregarded.

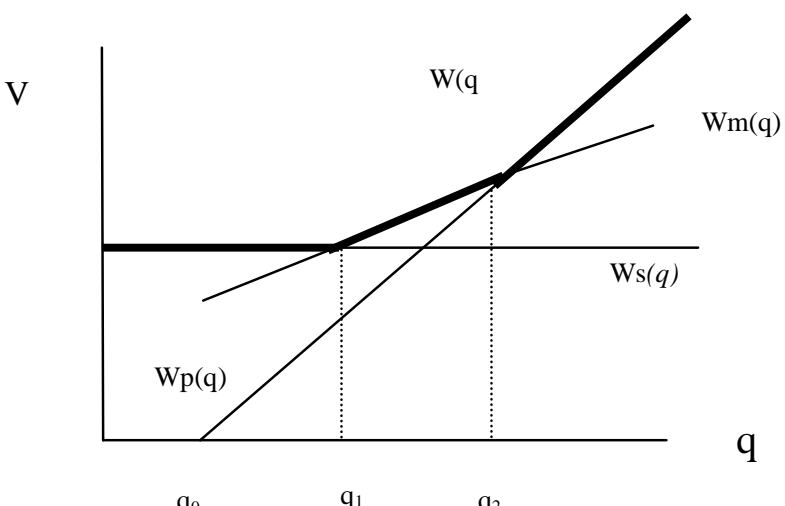

Figure 1. Relationship between expected wage $(W)$, workers quality $(q)$ and monitoring cost $(V)$.

In the presence of teamwork, individual output is not directly measurable, as teams are implemented due to the synergy generated by cooperation among team members, and rewards based solely on individual performance are hard to implement. Profit sharing provides a mechanism to link individual rewards to the team's performance.

In this model, the presence of profit sharing schemes, $W_{m}(q)>0$, depends on the monitoring costs and worker ability. In our setting worker ability is reflected in indicators like level of education or incomes. The size of firm has been used in many settings as an indicator of monitoring costs. We include in this setting the number of workers within an establishment performing the same job, denoted as job concentration. 
We therefore test empirically whether the presence of those characteristics increases the probability that a worker receives profit sharing or not. We might also find deviation from the theory in Finnish data, due to the presence of strong legislation and trade unionism. However, in doing so, we will check the importance of collective agreements and industrial sectors in the setting of profit sharing agreements between the two employer-employee parts in the labour market.

\section{CHARACTERISTICS OF THE FINNISH LABOUR MARKET}

The Finnish labour market is characterised by strong regulation and extensive trade unionism. Collective agreements signed between industries and trade unions are the basis for wage setting. A series of reforms in the labour market were carried out in the early 1990s. More decentralised bargaining was launched, allowing local bargaining and agreement at plant level. However, despite the move towards decentralisation, the main decisions about wage levels and working conditions are still in fact agreed at a centralised level. Contracts, which change the work and pay conditions, can be signed at the work-place level, but when no agreement is reached here it is the national collective agreement that applies. This means that either party can resist divergence from the national agreements. To reduce one parties resistance to divergence from central agreements, it may be in the interest of the firm to give employees a part of the profit in exchange for changes that raise the productivity of labour.

Profit sharing is not included in the collective agreements at the industry level, therefore parties may agree on profit sharing at the firm level. The bargaining position of employees in this regard is weak; once an agreement between trade unions and the employees confederation is reached, strikes to improve conditions at the local level are prohibited. However, firms may find it useful to introduce profit sharing to accomplish other objectives which deviate from collective agreements at the industry level.

Decisions in the labour market are usually influenced by institutional restrictions. This is especially the case in Finland, were the labour market is strongly regulated. Regulations regarding bonus payments and profit sharing vary among industries. For example in the metal industry profit sharing is included in the collective agreement, whereas in other industries it may be agreed at firm or individual level. 
Profit sharing constitutes only a small share of the workers' pay in Finland. ${ }^{4}$ Strikes are also not very common in Finland, partly due to tied legislation. Nevertheless, workers may occasionally use illegal strikes or absenteeism to express their dissatisfaction to unfavourable changes.

\section{THE DATA}

The data used in this study is obtained from the Confederation of Finnish Industry and Employers. It includes observations on most employees in Finnish industry for 19962000, limited to salaried employees. The data observations include a detailed description of individual characteristics, job type description and payments at an individual level. Information on individual characteristics such as age, gender, education, experience and seniority is included. Among the variables defining the job description we find professional status, job code, working hours, etc. Regarding the payment structure, in addition to the base salary, a number of other variables like fringe benefits, profit sharing and overtime payment are also included. These variables if necessary can be aggregated both at the firm and the plant level to study how the variables are related. The data also includes many more variables concerning workers, which enable creation of firm level control variables, such as the extent to which the firm employs personnel in $R \& D$ activities.

The summary statistics of the variables used in the regression statistical for profit sharing participants/non-participants separately and by pooling the two groups is given in Table 1.

The original data set is a linked employer-employee dataset. Regression analysis will be carried out at individual level. Our original dataset consists of 668218 observations of individual employees observed during 1996-2000. In a number of cases (7725) the education variable was missing reducing the sample to 660493 observation. The panel is unbalanced. We will restrict our analysis to two methods of pay. The first one is the Times Rates Salary defined as total yearly wage. The second is Profit Sharing Payments defined as the sum of various components also given as yearly payments. These

\footnotetext{
${ }^{4}$ For more details on profit sharing in Finland please see Meyersson-Milgrom et al. (2000) and OECD (1995).
} 
payments are associated with performance, although their definition varies from firm to firm. Nevertheless a common characteristic of performance related payment in Finnish industry is that it is often linked to firm overall productivity and profitability. According to the Confederation of Finnish Employers and Employees statistics for white-collar workers, almost $70 \%$ of performance related payments are based on firms' results or group performance, while only about $15 \%$ are based on individuals' own work (Teollisuus and Työnantajat, 2002).

As a dependent variable in our regression analysis we will use two definitions; the profit sharing share of earnings defined as the ratio of profit sharing to time rate payments per individual and year, and the logarithm of profit sharing payment per individual and year.

As independent variables we will use a number of relevant individual and firm characteristics. Individual characteristics including age, gender, education and seniority, are used in the main equation to test our hypothesis that individuals with higher ability and more capability to bear risk will prefer to work on performance related schemes. Firm level characteristics such as location, industrial sector and firm size are used in the selection equation as instruments to control the factor that not every individual can work under profit sharing schemes, even when s/he would be willing to do so. ${ }^{5}$ Absence of profit sharing schemes could be due to institutional restrictions like collective agreements, firm wage policy or negative results due to economic recession.

As mentioned, the use of profit sharing is expanded in the Finnish manufacturing sector. Around 55\% of employees received some kind of performance related payment in the sample years, while $45 \%$ worked only on a time rate basis. Despite the extension in use, profit sharing still constitutes a small share of employee compensation. From the summary statistics (Table 1) we see that the yearly wage differs among the two groups of employees distinguished by their participation in profit sharing schemes. On average participants have a $22.5 \%$ higher yearly wage. About $6 \%$ of the wage is due to profit sharing. Participants are also somewhat older (41.5/40.7), are more senior (14.0/12.7), work in an environment with a lower job concentration $(0.105 / 0.121)$ but work for

\footnotetext{
${ }^{5}$ Several studies show like evidence of a positive link between age of firms and wages. Kölling et al. (2002) one which using German data find such positive link. Here we do not have access to the age of firm or information on productivity of labour (measured e.g. as sale per employee).
} 
larger firms (2081/1748 employees). A larger share also holds a university degree $(0.339 / 0.279)$ and smaller numbers are female $(0.317 / 0.403){ }^{6}$ The dispersion of wages among the profit sharing group is lower (38\% of sample mean) than among the time rates group (49\%).

The correlation among variables (Table 2) shows that the level of yearly wage, employee age, firm size, residence of Southern Finland and a higher education promote profit sharing, while a higher female share, a higher job concentration and lower level of education negatively affects profit sharing. Seniority is found to be insignificant. Seniority and age are highly correlated (0.67). The same is true when intermediate and higher education levels (-0.80) are considered. This implies that these effects might be confounded. Remaining correlation coefficients among the explanatory variables is below 0.40 and indicate that collinearity is not a serious problem.

\section{THE EMPIRICAL FORMULATION}

In analysing profit sharing data and behaviour two issues are important: the propensity to participate in profit sharing, and the magnitude of profit sharing. A two-step procedure (Heckman 1979) is therefore considered as an appropriate model of analysing the data. The model contains two equations: a selection equation reflecting participation in profit sharing, and a regression equation on the level of profit sharing.

In this paper we will perform a Heckman maximum likelihood (ML) analysis, with the dichotomical variable measuring the existence of profit sharing as the dependent variable in the selection equation. The Heckman ML analysis differs from the original Heckman two-step procedure by the second steps estimation method. In the former an ML method is used, while in the latter it is an ordinary least squares method. The ML method is more efficient but at the cost of distributional assumptions. We assume two specifications of the second equation: using the percentage share of profit sharing to time rate payment, and using the logarithm of yearly profit sharing payment as dependent variables.

In order to account for possible parameter heterogeneity over time, initially, we treat the data as independent cross sections by running different cross sections, one for each year,

\footnotetext{
${ }^{6}$ The number in parenthesis corresponds to those of participants/non-participants.
} 
and we check for parameter stability. We contrast these individual years of result with those from a pooled data case. This two-stage approach allows us to control selectivity effects and endogeneity issues. Selectivity bias arises due to non-random discontinuity in individuals' observation over time and differences in the probability of profit sharing participation, while endogeneity arises because of the use of a profit sharing decision factor as an explanatory variable in the second equation. The basic model is derived from the optimisation rule:

$$
W_{i j t}=\alpha_{i j t}+\beta^{\prime} q_{i j t}
$$

where $W_{i j t}$ is compensation to individuals, and $q$ is a matrix of labour quality variables including measures of individual risk aversion and ability characteristics. The underlying regression relationship is of the form:

$$
Y_{i j t}=\beta^{\prime} X_{i j t}+\varepsilon_{i j t}
$$

where $\varepsilon_{i j t}$ is a ransom error term probably associated with individual $i$, working at firm $j$ in period $t$. It is assumed to be normally distributed with zero mean and with constant variance. The $X_{i j t}$ is a matrix containing the individual characteristics like age, gender and education. Education is represented by dummy variables for basic, intermediate and university levels of education. Seniority is measured as number of years working at the firm. The time rate wage is given in logarithm.

Two model specifications have been proposed and tested. In the first specification the dependent variable, Y, describes the individuals' percentage share of profit sharing to time rate wage expressed as:

$$
Y_{i j t}^{1}=\left(P S_{i j t} / W_{i j t}\right) \times 100
$$

where $P S_{i j t}$ is total yearly profit sharing payment, and $W_{i j t}$ is total yearly wage (time rates). In the second case the dependent variable describes the level of total yearly profit sharing payment in logarithm terms written as:

$$
Y_{i j t}^{2}=\ln \left(P S_{i j t}\right) .
$$

It is to be noted that the dependent variable is not always observed. The payment of bonuses is dependent on the results of the firm or some unit of it, and on the fact that the 
individual we observe is included in profit sharing schemes. No negative profit sharing is allowed. Therefore our dependent variable is left censored incorporating a nonnegative scale. This left censoring implies upward bias in standard regression coefficients.

To correct for this bias we use a selection approach and, as instruments, firm and work place characteristics that might influence the participation of individuals in profit sharing schemes, and subsequent distribution of profit sharing bonuses. The model is a combination of a classical regression and a binary selection criterion model written as

(6a) $\quad Y=\beta^{\prime} X_{1}+\varepsilon$

$$
Z^{*}=\alpha^{\prime} X_{2}+u
$$

where the residuals $\varepsilon, u$ are normally distributed with zero means, variances $\sigma_{\varepsilon}^{2}$ and $\sigma_{u}^{2}$ and covariance $\rho \sigma_{\varepsilon} \sigma_{u}$. The $Z^{*}$ variable is not observed, the observed counterpart is $Z=1$ if $Z^{*}>0$, else 0 . The variables $Y$ and $X_{1}$ are observed only when $Z=1$. The two vectors of $X_{1}$ and $X_{2}$ partly overlap. The model is estimated by maximum likelihood (Greene 2000). The variance $\sigma_{u}^{2}$ cannot be estimated, so it is normalised to 1.0. In the selected sample

$$
E\left[Y \mid X_{1}, Z=1\right]=\beta^{\prime} X_{1}+\left(\rho \sigma_{\varepsilon} \sigma_{u}\right)\left(\phi\left(\alpha^{\prime} X_{2}\right) / \Phi\left(\alpha^{\prime} X_{2}\right)\right)=\beta^{\prime} X_{1}+\left(\rho \sigma_{\varepsilon}\right) \lambda .
$$

The Heckman ML selection model provides consistent, asymptotically efficient estimates for all the parameters. The selectivity is accounted for by adding the inverted Mill's ratio $\lambda=\phi\left(\alpha^{\prime} X_{2}\right) / \Phi\left(\alpha^{\prime} X_{2}\right)$ to the set of $X_{1}$ variables. A significant coefficient is an indication of the presence of a selection bias and the coefficients sign the direction of bias. The $X_{2}$ matrix contains our instruments, and include variables that would strongly influence the fact that an individual receives some kind of profit sharing payment, but that do not influence the level or proportion of his/her compensation paid in bonuses.

The $X_{2}$ matrix includes firm characteristics, like firm size (measured as the number of employees), and job concentration (measured as the number of individuals in the same activity group) as proxies for monitoring cost. It also contains other control variables 
that might influence the managers decision to share profits, like workers occupation, location and industrial sector dummies.

The variable showing the proportion of individuals within a firm performing the same task, represented as $\operatorname{JCON}_{i j t}$ is limited to the interval $(0,1)$. It is constructed as follows: The original linked dataset includes the variable $T R_{i j t}(\mathrm{R}=1,2, \ldots, 75)$ which takes the value 1 if individual $i$, working at firm $j$, performs task $R$ in period $t$. To obtain firm level observations we constructed 75 new variables labelled $T R$. Each $T R$-variable shows the proportion of individuals that perform task $R$ within a firm.

$$
J C O N=\sum_{i=j, i \in j}^{n, j} T R_{i j t} / n_{j} \text { for } \mathrm{j}=1,2, \ldots, \mathrm{J}, \mathrm{t}=1,2, \ldots, \mathrm{T} \text { and } \mathrm{R}=1,2, \ldots, 75 .
$$

\section{EMPIRICAL RESULTS}

\section{A. The estimation results}

The Heckman model in (6a) and (6b) are estimated for each cross section separately, pooling all years using ML estimation method. As dependent variables the proportion of profit sharing $\left(Y^{1}\right)$ and the level of profit sharing $\left(Y^{2}\right)$ as described in Section 5 have been used. Descriptive Statistics of the variables used in our regressions are given in Table 1 and the correlation matrix of the variables is shown in Table 2. The parameter estimates for various model specifications are reported in Tables 3 and 4. All key parameters $(\rho, \sigma$ and $\lambda)$ are statistically significant but in some cases differ by sign and size depending on the model specification. In the level formulation the pooled parameters are jointly insignificant, affected by 1996 data. In a pooled probit model the frequency of correctly predicted participants is $67.6 \%$, while those of non-participants is $71.5 \%$ (see Table 5). The wrong predicted participant (non-participants) is $32.4 \%$ $(28.5 \%)$.

Profit sharing still constitutes only a small share of workers' pay in Finland, but its use has increased significantly through the years in our sample. In 1996 only $29 \%$ of whitecollar workers in the Finnish manufacturing sector received some kind of performance related payment, against almost $53 \%$ in year 2000 (see Figure 2). We also find an expansion of profit sharing schemes at industry level. As mentioned, from 1998 all 
workers in certain industry sectors like computer and telecommunications received some part of their compensation package in the form of profit sharing, whereas in others industries like leather and shoe manufacturing no profit sharing was distributed. ${ }^{7}$

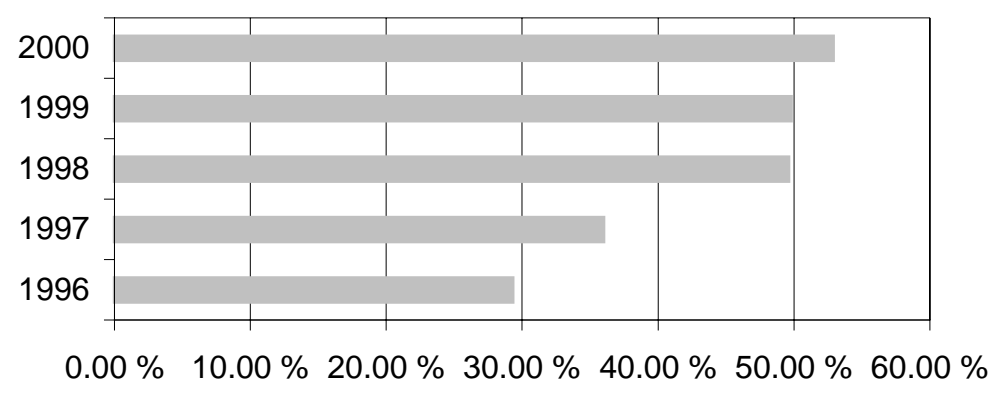

Figure 2. Proportion of individuals receiving some kind of performance related paymnt.

The increased application of profit sharing has been accompanied by an increase in the amount of compensation paid with this type of incentive device. In 1996 the mean time rate wage in the Finnish manufacturing sector was 164180 Finnish Marks (FIM) and the mean profit sharing payment was $3295 \mathrm{FIM}^{8}$. In 2000 the mean time rate wage was 175964 while the mean profit sharing payment was 6661 FIM. Profit sharing still constitutes only a small share of workers' pay in Finland, but its importance is growing as its use is extended in the Finnish economy. Profit sharing is equivalent to $3 \%$ of total yearly wage in the entire sample and $6 \%$ of the wage for those participating in profit sharing schemes (Table 1). The development of time rate and profit sharing over 1996200 is shown in Figure 3.

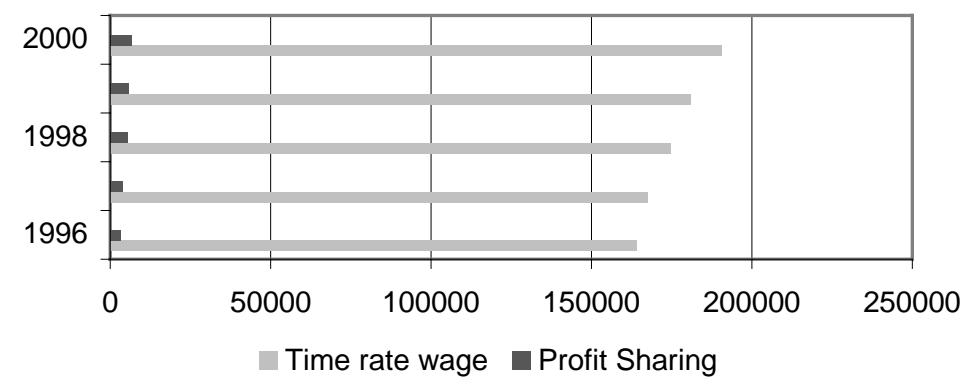

Figure 3. Wage and profit sharing in Finnish manufacturing.

\footnotetext{
${ }^{7}$ In order to conserve space results on differences in profit sharing by industrial sectors are not reported in this paper, but are available from the authors upon request.

${ }^{8}$ Based on sample mean containing individuals not receiving any profit sharing as well.
} 
In order to test the stability of the parameter estimates over time the model is estimated both in pooled and cross sectional forms. The large annual samples and log likelihood values indicate that slope coefficients are statistically different over the period. Pooling the data should ideally be accompanied by allowances for time heterogeneous parameters, however this would cause difficulties in the estimation and interpretation of the results and convergence of the model. We decided to estimate the model both in forms of pooled and separately for individual years. In the analysis of the results, if not indicated otherwise, we refer to the pooled model.

The results from the selection equation presented in Table 3 and 4 show that residents of Southern Finland have a lower propensity to participate in profit sharing. As expected, an increase in the size of firm increases the incentives of firms to employ performance based payments. Job concentration variable also negatively affects profit sharing participation. These patterns hold regardless of the definition of the dependent variables in the regression equation. In going from a pooled model to individual cross sections, with the exception of job concentration in 1999, the signs and significance do not change, but the size of some coefficients does change somewhat.

From the results reported in Tables 3 and 4 we observe that the logarithm of the time rate wage is the key variable in the determination of profit sharing at the individual level and an explanation of the variations in profit sharing. This is the case in both model specifications (level and proportion of profit sharing). However its importance decreases over time as the use of profit sharing becomes more common in the Finnish manufacturing. The yearly wage positively affects profit sharing participation, while age, seniority, lower levels of education and female share affects negatively. The elasticity of profit sharing with respect to time rate wage decreases from 1.3855 in 1996 to 1.046 in 2000 (see Table 4.B, level equation specification). The decrease in the logarithm of the time wage rate coefficient is sharper in the share specification (See Table 3.B), ranging from 0.8631 in 1996 to -2.7146 in 2000. The negative sign in this coefficient in years 1999 and 2000 might derive from the way the dependent variable is constructed. In the share specification the dependent variable is the profit sharing payment divided by the time rate payment. An increase of one unit in the time rate wage has a positive effect on the numerator (high wage workers receive more profit sharing), but also increases the denominator by one unit. If the elasticity of profit sharing with 
respect to time rate wage were less than unity, it would imply a negative sign of this coefficient. Depending on how the dependent variable is defined, several coefficients change sign in the pooled and different cross sectional models.

\subsection{Profit sharing and the difficulty of monitoring worker activity}

We find empirical evidence that larger firms use more extensively profit sharing schemes to reward workers. This could be related to our economic theory, considering firm size as an indicator for the difficulty to monitor worker activity. Small firms where individual performance is more observable do not need to use workers' compensation above the market level to induce workers to exert a higher effort. The positive sign of the $\log$ size coefficient in our selection equation model (Tables 3.A and 4.A) gives some evidence of the positive link between the firms' size and the method of pay. The size heterogeneity and greater flexibility of the firms and their operations provide interesting opportunities to investigate the impact of profit sharing on behaviour of firms and the practice of profit sharing and its impact on the performance of workers and firms.

Individuals performing a task that is more common within a particular firm have an ambiguous effect on the probability of receiving profit sharing schemes. The sign of the job concentration variable in the pooled regression is negative (Tables 3.A and 4.A), but it takes both positive and negative values in the different cross sections and in most cases is highly significant. This might be due to the fact that job concentration is correlated with the workers' occupation within firm. The differences in signs over time might reflect that it is the workers' activity (and not the total number of workers performing the same task) that is decisive in their inclusion into profit sharing schemes.

Certain occupations such as sales activities, production and product management have a highly positive and significant effect on the probability that a worker is included in profit sharing schemes. This reflects the fact that in some activities profit sharing bonuses are more easily applicable for various reasons, i.e. output is more easily measurable (sales). We find that a high number of activities that are statistically insignificant or have a negative impact on the probability of introducing profit sharing refer to activities that are not directly related to production, like accounting or clerical work. We also find a higher significance for occupations that are elevated in the 
hierarchy of an organisation like management compared to those in the lower level of administration. ${ }^{9}$

\subsection{Profit sharing and the economic sector}

The importance of the industries in which individuals work has to be outlined. We have included industry dummies in the selection equations, which all turned out to be statistically significant in every year studied. Moreover, we find that profit sharing schemes appear for all individuals in the telecommunication sectors ${ }^{10}$ from 1998. In this case, the use of profit sharing might have been introduced by wage flexibility considerations, rather than incentive concerns. In industries where profit sharing is agreed collectively, profit sharing schemes are a result of a bargaining process and can be viewed by firms as a tool to introduce wage flexibility, while workers see it as a possible increase in their payments not otherwise achieved while bargaining on the base wage. It could also be the case that firms working in certain economic sectors just pay this type of reward for performance to prevent more able workers changing job, moving to the competitor firms in the same sector.

We find the probability of profit sharing increases in firms belonging to sectors like telecommunications, metal and electronic production, forest industry and other sectors characterised by large production units where innovation in the production process is relatively important. In traditional sectors like handcraft or the textile industry those practises are not so influential to the practice of profit sharing.

\subsection{Profit sharing and individual characteristics}

We have identified the activities and industries in which it is more probable to find evidence of compensation to workers in the form of profit sharing schemes. In the following we investigate which type of individuals will prefer to work in a setting where only time rates are paid, and who will be willing to receive part of their total compensation in the form of profit sharing.

\footnotetext{
${ }^{9}$ Detailed descriptions of occupation categories and their estimated regression coefficient are available from the authors on request.

${ }^{10}$ In some other sectors like leather and shoe manufacturing sector, no profit sharing was distributed to any worker in any of the years observed.
} 
Profit sharing involves uncertainty in compensation for the worker, and have stated that certain individuals are more able to bear the risk and are more prone to share this risk with their employer. In this sense we find that both the proportion and level of profit sharing that an individual receives increase with the time wage and decreases with age (Tables 3.B and 4.B shows details). We note that older individuals with lower time compensation will be more risk adverse, while males, younger, with higher income and holding a university degree are more willing to bear the risk of participation in profit sharing.

We find a positive impact of university education on both the level and the proportion of profit sharing that a worker receives. This result supports the hypothesis that risksharing agreements would be more common among highly educated (high wage) workers. Another explanation to this behaviour could be the fact that education is a signal of a worker's ability. Workers with high ability may apply for positions where compensation is more linked to their performance (like in a profit sharing schemes). It might also reflect the fact that those with a higher education attain jobs at a higher position in the firm, and therefore capitalise from more profit sharing. Although, such a link would have been captured by the occupation dummy. The impact of seniority is close to zero, both in the level equation and in the proportion equation, although significant in most cases.

\section{SUMMARY AND CONCLUSIONS}

The use of profit sharing has increased considerably in Finland during 1996-2000. Following centralised or decentralised agreements between employer and employee organizations in some sectors like telecommunications, all white-collar workers receive some type of performance-based payments.

We sought to link profit sharing to individual and firm characteristics using a unique employer-employee matched Finnish panel data. We find evidence of strong and positive association between the size of the firm and the practice of profit sharing incentives. We also find that at the individual level the logarithm of wage is the leading variable in the determination of the level of profit sharing. However, other types of links are less obvious. 
Industry dummies are found to be statistically significant and of great importance. This is an indication of the presence of heterogeneity in a firms behaviour in the adoption of performance based payments. We conclude that the decision whether to practice profit sharing schemes or not is highly influenced by the economic sector that the firm is part of. In some cases, profit sharing is agreed as part of collective wage setting or is otherwise a separate agreement. Under such conditions individual firms cannot use this incentive device discretionarily, where the use of profit sharing is a result of the bargaining process and might have been induced by wage flexibility considerations.

We also find that certain activities like sales and production management are more susceptible for inclusion in profit sharing schemes than others. More individuals receive higher levels of profit sharing as we move upward in the hierarchy of a firm. This is confirmed by finding that profit sharing is positively associated with the individual employee's level of education.

Regarding individual characteristics, we find empirical evidence that the use of level and proportion of profit sharing is higher among those individuals that are more able to bear risk. The time rate wage seems to be the leading variable in our regressions, disregarding whether the log of profit sharing or the proportion of profit sharing to time rate is used as the dependent variable.

Regarding the econometric methodology used, we would like to point out that the Heckman ML selection model is sensitive to the model specification. The importance of the instruments being correctly specified has to be highlighted. Unfortunately we do not have access to variables such as the firms' productivity, profitability or capital intensity, traditionally used as instruments in this type of analysis. We have tried to compensate for these types of shortages by creating firm level variables like firm size and the job concentration. The results show that there exists significant selection effect and that in our model the specifications should account for this by using the Heckman sample selection estimation method. The share specification is a preferred specification compared to level of profit sharing. 


\section{REFERENCES}

Bauer T.K. (2003), Flexible Workplace Practices and Labor Productivity, IZA Discussion Paper No. 700.

Brown C. (1990), Firms Choice of Method of Pay, Industrial and Labor Relations Review 43, 165-182.

Cahuc, P. and Dormont, B. (1997), Profit-sharing: Does it increase productivity and employment? A theoretical model and empirical evidence on French micro data, Labour Economics 1, 293-319.

Fitzroy, F. and Kraft, K. (1987), Cooperation, Productivity and Profit Sharing, Quarterly Journal of Economics 102, 23-35.

Greene, W.H. (2000), Econometric Analysis, Fourth Edition, Prentice Hall International Inc.

Heckman J.J. (1979), Sample Selection Bias as a Specification Error, Econometrica 47, 153-161.

Holmström B. and Milgrom P. (1991), Multitask Principal-Agent Analyses: Incentive Contracts, Assets Ownership and Job Design, Journal of Law and Economic Organisation 7, 24-25.

Holmström B. and Milgrom P. (1994), The Firm as an Incentive System, American Economic Review 84(4), 972-991.

Kölling A., C. Schnabel and J. Wagner (2002), Establishment Age and Wages: Evidence from German Linked Employer-Employee Data, IZA Discussion Paper No. 679.

Lazear E.P. (1995), Personnel Economics, The MIT Press, Cambridge, Massachusetts.

Margolis D.N. and K.G. Salvanes (2001), Do Firms Really Share Rents with Their Workers?, IZA Discussion Paper No. 330.

Meyersson-Milgrom E.M., Petersen T. and Asplund R. (2000), Pay, Risk and Productivity: The case of Finland, 1980-1996, ETLA KeskusteluaiheitaDiscussion papers, No 743.

OECD (1995), Profit Sharing in OECD Countries, OECD Employment Outlook, Paris.

Prendergast C. (1999), The Provision of Incentives in Firms, Journal of Economic Literature XXXVII, 7-63.

Teollisuus and Työnantajat (2002), Tulospalkkaus 2002. 
Table 1. Summary statistics of the Finnish data, 1996-2000.

\begin{tabular}{lrrrr}
\hline \multicolumn{1}{c}{ Variable } & \multicolumn{1}{c}{ Mean } & Std. Dev. & Minimum & Maximum \\
\hline A. All employees (n=660493) & & & & \\
\hline Dummy for Profit Sharing & 0.4522 & 0.4977 & 0 & 1 \\
Yearly Wage (FIM) & 178041.0000 & 79788.0000 & 1 & 1098940 \\
Profit Sharing Payments (FIM) & 5375.0000 & 13210.5000 & 0 & 650086 \\
Age & 41.1000 & 9.5930 & 17 & 97 \\
Women & 0.3430 & 0.4812 & 0 & 1 \\
Firm size (No. of employees) & 1987.9000 & 3363.8000 & 1 & 15660 \\
South Finland & 0.5241 & 0.4994 & 0 & 1 \\
Job concentration & 0.1136 & 0.1373 & 0 & 1 \\
Seniority & 13.3200 & 10.4399 & 0 & 54 \\
Basic education & 0.1166 & 0.3210 & 0 & 1 \\
Intermediate education & 0.6032 & 0.4892 & 0 & 1 \\
Higher education & 0.3064 & 0.4610 & 0 & 1 \\
\hline B. Employees receiving incentive related payments & $(\mathrm{n}=294427)$ & & \\
Yearly Wage (FIM) & 197935.0000 & 75777.6000 & 19 & 1098940 \\
Profit Sharing Payments (FIM) & 11887.0000 & 17565.0000 & 1 & 650086 \\
Age & 41.5200 & 9.5300 & 18 & 69 \\
Women & 0.3170 & 0.4653 & 0 & 1 \\
Firm size (No. of employees) & 2079.6000 & 3307.3000 & 1 & 15660 \\
South Finland & 0.5115 & 0.4999 & 0 & 1 \\
Job concentration & 0.1053 & 0.1218 & 0 & 1 \\
Seniority & 14.018 & 10.3900 & 0 & 53 \\
Basic education & 0.1077 & 0.3100 & 0 & 1 \\
Intermediate education & 0.5757 & 0.4943 & 0 & 1 \\
Higher education & 0.3389 & 0.4733 & 0 & 1 \\
\hline C. Employees receiving only time rate & payments (n=366066) & & \\
Yearly Wage (FIM) & 161621.0000 & 79277.6000 & 1 & 1037576 \\
Age & 40.7500 & 9.6300 & 17 & 97 \\
Women & 0.4033 & 0.4910 & 0 & 1 \\
Firm size (No of employees) & 1747.9000 & 3402.4000 & 1 & 15660 \\
South Finland & 0.5346 & 0.4988 & 0 & 1 \\
Job concentration & 0.1205 & 0.1486 & 0 & 1 \\
Seniority & 12.744 & 10.4500 & 0 & 54 \\
Basic education & 0.1240 & 0.3300 & 0 & 1 \\
Intermediate education & 0.6261 & 0.4838 & 0 & 1 \\
Higher education & 0.2794 & 0.4487 & 0 & 1 \\
\hline & & & & \\
\hline
\end{tabular}


Table 2. Pearson correlation matrix $(n=660493)$.

\begin{tabular}{|c|c|c|c|c|c|c|c|c|c|c|c|}
\hline & $\begin{array}{l}\text { Profit } \\
\text { sharing }\end{array}$ & Wage & Age & Women & $\begin{array}{l}\text { Firm } \\
\text { Size }\end{array}$ & South & $\begin{array}{l}\text { Job } \\
\text { Conc. }\end{array}$ & $\begin{array}{l}\text { Senio- } \\
\text { rity }\end{array}$ & $\begin{array}{l}\text { Basic } \\
\text { Educ. }\end{array}$ & $\begin{array}{l}\text { Inter. } \\
\text { Educ. }\end{array}$ & $\begin{array}{l}\text { High } \\
\text { Educ. }\end{array}$ \\
\hline Profit Sharing & 1 & & & & & & & & & & \\
\hline Yearly Wage & $0.372 \mathrm{a}$ & 1 & & & & & & & & & \\
\hline Age & $0.027 \mathrm{a}$ & $0.265 \mathrm{a}$ & 1 & & & & & & & & \\
\hline Women & $-0.122 \mathrm{a}$ & $-0.391 \mathrm{a}$ & $-0.027 \mathrm{a}$ & 1 & & & & & & & \\
\hline Firm Size & $0.015 \mathrm{a}$ & 0.0012 & $-0.156 a$ & $-0.006 a$ & 1 & & & & & & \\
\hline South Finland & $0.028 \mathrm{a}$ & $0.083 \mathrm{a}$ & $-0.044 a$ & $0.014 \mathrm{a}$ & $0.074 \mathrm{a}$ & 1 & & & & & \\
\hline Job Conc. & $-0.015 a$ & $-0.083 a$ & $-0.107 \mathrm{a}$ & $-0.160 \mathrm{a}$ & $-0.048 \mathrm{a}$ & $-0.034 \mathrm{a}$ & 1 & & & & \\
\hline Seniority & 0.001 & $0.145 \mathrm{a}$ & $0.670 \mathrm{a}$ & $0.041 \mathrm{a}$ & $-0.108 \mathrm{a}$ & $-0.085 a$ & $-0.136 a$ & 1 & & & \\
\hline Basic Educ. & $-0.036 a$ & $-0.125 a$ & $0.211 \mathrm{a}$ & $0.124 \mathrm{a}$ & $-0.012 \mathrm{a}$ & $0.015 \mathrm{a}$ & $-0.023 a$ & $0.254 \mathrm{a}$ & 1 & & \\
\hline Interm. Educ. & $-0.084 a$ & $-0.238 a$ & $0.031 \mathrm{a}$ & $0.097 \mathrm{a}$ & $-0.075 a$ & $-0.068 \mathrm{a}$ & $-0.007 a$ & $0.098 \mathrm{a}$ & $-0.303 a$ & 1 & \\
\hline Higher Educ. & $0.107 \mathrm{a}$ & $0.323 \mathrm{a}$ & $-0.162 a$ & $-0.183 a$ & $0.076 \mathrm{a}$ & $0.058 \mathrm{a}$ & $0.025 \mathrm{a}$ & $-0.253 a$ & $-0.242 \mathrm{a}$ & $-0.805 a$ & 1 \\
\hline
\end{tabular}

Note: Significant at less than $1 \%$ (a) level of significance. 
Table 3. Maximum likelihood parameter estimates of profit sharing (share) model.

3.A Probit model of participation in profit sharing, equation $6 \mathrm{~b}$

\begin{tabular}{lrrrrrr}
\hline Variable & Pooled & 1996 & 1997 & 1998 & 1999 & 2000 \\
\hline South Finland & $-0.0142 \mathrm{a}$ & $-0.0121 \mathrm{a}$ & $-0.0048 \mathrm{a}$ & $-0.0372 \mathrm{a}$ & $-0.1451 \mathrm{a}$ & $-0.2230 \mathrm{a}$ \\
Log firm size & $0.0026 \mathrm{a}$ & -0.0003. & $0.0041 \mathrm{a}$ & $0.0032 \mathrm{a}$ & $0.1654 \mathrm{a}$ & $0.2029 \mathrm{a}$ \\
Job concentration & $-0.0720 \mathrm{a}$ & $-0.0420 \mathrm{a}$ & $-0.0553 \mathrm{a}$ & $-0.2346 \mathrm{a}$ & $0.1255 \mathrm{a}$ & $-0.5813 \mathrm{a}$ \\
Constant term & $-0.8091 \mathrm{a}$ & $-0.7062 \mathrm{a}$ & $-0.5560 \mathrm{a}$ & $-0.1862 \mathrm{a}$ & 0.4022. & 0.1172. \\
\hline
\end{tabular}

Note 1: The dependent variable is a dummy variable that takes the value 1 if the individual has received compensation related to profit sharing in that year, else 0 .

Note 2: 75 occupational dummies and 30 industry dummies are included. In addition year dummies are also included in pooled regression.

\begin{tabular}{lrrrrrr}
\hline \multicolumn{7}{l}{ 3.B Regression model of profit sharing, equation 6a } \\
\hline Variable & Pooled & 1996 & 1997 & 1998 & 1999 & 2000 \\
\hline Log yearly wage & $0.3751 \mathrm{a}$ & $0.8631 \mathrm{a}$ & $0.36195 \mathrm{a}$ & $0.6930 \mathrm{a}$ & $-0.6081 \mathrm{a}$ & $-2.7146 \mathrm{a}$ \\
Age & $-0.0047 \mathrm{a}$ & $-0.0094 \mathrm{a}$ & $-0.0035 \mathrm{a}$ & $-0.0103 \mathrm{a}$ & $-0.0177 \mathrm{a}$ & $0.0096 \mathrm{a}$ \\
Seniority & $0.0010 \mathrm{a}$ & $0.01214 \mathrm{a}$ & $0.0047 \mathrm{a}$ & -0.0004 & $-0.0392 \mathrm{a}$ & $-0.0370 \mathrm{a}$ \\
Interm. Educ. & $0.0564 \mathrm{a}$ & -0.0535 & -0.0101. & $-0.0883 \mathrm{a}$ & 0.1145. & $0.1341 \mathrm{c}$ \\
Higher educ. & $0.1037 \mathrm{a}$ & $0.0977 \mathrm{~b}$ & - & $-0.0988 \mathrm{a}$ & $0.3644 \mathrm{a}$ & $1.2422 \mathrm{a}$ \\
Women & $-0.1023 \mathrm{a}$ & $-0.2838 \mathrm{a}$ & $-0.1356 \mathrm{a}$ & $-0.1669 \mathrm{a}$ & $-0.8362 \mathrm{a}$ & $-1.1855 \mathrm{a}$ \\
Constant term & $-8.9964 \mathrm{a}$ & $-14.2138 \mathrm{a}$ & $-10.4545 \mathrm{a}$ & $-7.7169 \mathrm{a}$ & $15.0018 \mathrm{a}$ & $39.1013 \mathrm{a}$ \\
\hline
\end{tabular}

Note 1: The dependent variable is the yearly percentage share of profit sharing (total yearly profit sharing payments divided by yearly time rate wage times 100).

Note 2: Year dummies are included in pooled regression.

\begin{tabular}{lrrrrrr}
\hline \multicolumn{6}{l}{ Common parameters } \\
\hline Variable & Pooled & 1996 & 1997 & 1998 & 1999 & 2000 \\
\hline $\mathrm{N}$ & 660493 & 128851 & 126697 & 133511 & 134970 & 136464 \\
Censored, PS=0 & 366066 & 89181 & 82581 & 64585 & 65676 & 64043 \\
Log likelihood & -1292158 & -187916 & -214462 & -286763 & -309939 & -314680 \\
$\rho$ & $0.9996 \mathrm{a}$ & $0.9978 \mathrm{a}$ & $0.9999 \mathrm{a}$ & $0.9987 \mathrm{a}$ & $-0.1026 \mathrm{a}$ & $-0.0732 \mathrm{a}$ \\
$\sigma$ & $9.2894 \mathrm{a}$ & $8.9863 \mathrm{a}$ & $-12.4427 \mathrm{a}$ & $8.1428 \mathrm{a}$ & $6.5649 \mathrm{a}$ & $6.0033 \mathrm{a}$ \\
$\lambda$ & $9.2857 \mathrm{a}$ & $8.9670 \mathrm{a}$ & $12.4414 \mathrm{a}$ & $8.1321 \mathrm{a}$ & $-0.6739 \mathrm{a}$ & $-0.4386 \mathrm{a}$ \\
LR Test of: & $183819.75 \mathrm{a}$ & $16546.51 \mathrm{a}$ & $43696.93 \mathrm{a}$ & $28647.57 \mathrm{a}$ & $70.92 \mathrm{a}$ & $40.69 \mathrm{a}$ \\
Indep. Equ $\left(\chi_{1}^{2}\right)$ & & & & & & \\
\hline
\end{tabular}

Note: Significant at less than 1\%(a), 1-5\%(b), 5-10\%(c), and more than $10 \%$ (.) levels of significance. 
Table 4. Maximum likelihood parameter estimates of profit sharing (level) model.

\begin{tabular}{|c|c|c|c|c|c|c|}
\hline \multicolumn{7}{|c|}{ 4.A Probit model of participation in profit sharing, equation $6 \mathrm{~b}$} \\
\hline Variable & Pooled & 1996 & 1997 & 1998 & 1999 & 2000 \\
\hline South Finland & $-0.1434 \mathrm{a}$ & $0.0367 \mathrm{a}$ & $-0.2808 \mathrm{a}$ & $-0.2060 \mathrm{a}$ & $-0.1233 \mathrm{a}$ & $-0.2199 a$ \\
\hline Log firm size & $0.1219 \mathrm{a}$ & $0.0066 \mathrm{a}$ & $0.1208 \mathrm{a}$ & $0.1738 \mathrm{a}$ & 0.1639 a & $0.1986 \mathrm{a}$ \\
\hline Job concentr. & $-0.2716 \mathrm{a}$ & $-0.4664 \mathrm{a}$ & -0.8078 a & 0.0566 & $0.2351 \mathrm{a}$ & $-0.5207 \mathrm{a}$ \\
\hline Constant term & $-1.8466 \mathrm{a}$ & $-1.764 \mathrm{a}$ & $-1.9099 \mathrm{a}$ & $-0.7533 \mathrm{a}$ & 0.1806 & 0.2258 \\
\hline \multicolumn{7}{|c|}{$\begin{array}{l}\text { Note 1: The dependent variable is a dummy variable that takes the value lif the individual has received } \\
\text { compensation related to profit sharing in that year, else } 0 \text {. }\end{array}$} \\
\hline \multicolumn{7}{|c|}{$\begin{array}{l}\text { Note 2: } 75 \text { occupational dummies and } 30 \text { industry dummies are included. In addition year dummies are also } \\
\text { included in pooled regression. }\end{array}$} \\
\hline \multicolumn{7}{|c|}{ 4.B Regression model of profit sharing, equation $6 \mathrm{a}$} \\
\hline Variable & Pooled & 1996 & 1997 & 1998 & 1999 & 2000 \\
\hline Log yearly wage & $1.1838 \mathrm{a}$ & $1.3855 \mathrm{a}$ & $1.388 \mathrm{a}$ & $1.1852 \mathrm{a}$ & $1.1167 \mathrm{a}$ & $1.046 \mathrm{a}$ \\
\hline Age & $-0.0045 \mathrm{a}$ & $-0.0075 \mathrm{a}$ & $-0.0057 \mathrm{a}$ & $-0.0039 \mathrm{a}$ & -0.0008 & $-0.0017 \mathrm{a}$ \\
\hline Seniority & $-0.0040 \mathrm{a}$ & $0.0046 \mathrm{a}$ & -0.0004 & $-0.0067 \mathrm{a}$ & $-0.0087 \mathrm{a}$ & $-0.0048 \mathrm{a}$ \\
\hline Interm. educ. & -0.0045 & $-0.0303 b$ & $0.0204 \mathrm{c}$ & $-0.0954 \mathrm{a}$ & $0.0587 \mathrm{a}$ & 0.0011 . \\
\hline Higher educ. & $0.0576 \mathrm{a}$ & $0.0398 \mathrm{~b}$ & - & -0.0100 & $0.1143 \mathrm{a}$ & $0.0625 \mathrm{a}$ \\
\hline Women & $0.0282 \mathrm{a}$ & $0.0645 \mathrm{a}$ & $0.0575 \mathrm{a}$ & $0.0710 \mathrm{a}$ & $0.0353 \mathrm{a}$ & -0.0121 \\
\hline Constant term & $-5.2817 \mathrm{a}$ & $-7.7220 a$ & $-8.241 \mathrm{a}$ & $-5.2688 \mathrm{a}$ & $-4.2328 \mathrm{a}$ & $-3.320 a$ \\
\hline
\end{tabular}

Note 1: The dependent variable is the logarithm of yearly profit sharing payment.

Note 2: Year dummies are included in pooled regression equation.

Common parameters

\begin{tabular}{lrrrrrr}
\hline Variable & Pooled & 1996 & 1997 & 1998 & 1999 & 2000 \\
\hline $\mathrm{N}$ & 660493 & 128851 & 126697 & 133511 & 134970 & 136464 \\
Censored, PS=0 & 366066 & 89181 & 82581 & 64585 & 65676 & 64043 \\
Log likelihood & -801317 & -124477 & -136147 & -173864 & -174421 & -175924 \\
$\rho$ & $-0.0007 \mathrm{a}$ & $-0.0086 \mathrm{a}$ & $0.3800 \mathrm{a}$ & $0.1021 \mathrm{a}$ & $-0.5231 \mathrm{a}$ & $-0.5273 \mathrm{a}$ \\
$\sigma$ & $0.9521 \mathrm{a}$ & $0.9772 \mathrm{a}$ & $1.0680 \mathrm{a}$ & $0.9718 \mathrm{a}$ & $0.9994 \mathrm{a}$ & $0.9518 \mathrm{a}$ \\
$\lambda$ & $-0.0007 \mathrm{a}$ & $-0.0084 \mathrm{a}$ & $0.4059 \mathrm{a}$ & $0.0992 \mathrm{a}$ & $-0.5228 \mathrm{a}$ & $-0.5019 \mathrm{a}$ \\
LR Test of & 0.01. & 0.19. & $243.92 \mathrm{a}$ & $50.74 \mathrm{a}$ & $819.92 \mathrm{a}$ & $694.36 \mathrm{a}$ \\
Indep. Equ. $\left(\chi^{2}{ }_{1}\right)$ & & & & & & \\
\hline
\end{tabular}

Note: Significant at less than 1\%(a), 1-5\%(b), and 5-10\%(c), and more than $10 \%($.$) levels of significance.$ 
Table 5. Tabulation of observed versus predicted values based on the pooled Probit model.

\begin{tabular}{l|rrr}
\hline \multicolumn{3}{c}{ Predicted values } \\
\hline Observed values & Non-profit sharing PS=0 & Profit sharing PS=1 & Total \\
\hline Non-profit sharing (PS=0) & $252534(71.5 / 72.6)$ & $100423(28.5 / 33.5)$ & $352957(100 / 54.5)$ \\
Profit sharing (PS=1) & $95266(32.4 / 27.4)$ & $199161(67.6 / 66.5)$ & $294427(100 / 45.5)$ \\
Total & $347800(53.7 / 100)$ & $299584(46.3 / 100)$ & $647384(100 / 100)$ \\
\hline
\end{tabular}

Note: Frequency number (percentage share of row/column). 


\section{IZA Discussion Papers}

\begin{tabular}{|c|c|c|c|c|}
\hline No. & Author(s) & Title & Area & Date \\
\hline 761 & E. P. Lazear & $\begin{array}{l}\text { Output-Based Pay: Incentives, Retention or } \\
\text { Sorting? }\end{array}$ & 5 & $04 / 03$ \\
\hline 762 & $\begin{array}{l}\text { M. Gerfin } \\
\text { R. E. Leu }\end{array}$ & $\begin{array}{l}\text { The Impact of In-Work Benefits on Poverty and } \\
\text { Household Labour Supply - A Simulation Study } \\
\text { for Switzerland }\end{array}$ & 3 & $04 / 03$ \\
\hline 763 & $\begin{array}{l}\text { M. Biewen } \\
\text { S. P. Jenkins }\end{array}$ & $\begin{array}{l}\text { Estimation of Generalized Entropy and Atkinson } \\
\text { Inequality Indices from Complex Survey Data }\end{array}$ & 5 & $04 / 03$ \\
\hline 764 & P. A. Puhani & $\begin{array}{l}\text { A Test of the 'Krugman Hypothesis' for the } \\
\text { United States, Britain, and Western Germany }\end{array}$ & 2 & $04 / 03$ \\
\hline 765 & W. Schnedler & $\begin{array}{l}\text { On the Prudence of Rewarding A While Hoping } \\
\text { for B }\end{array}$ & 5 & $04 / 03$ \\
\hline 766 & $\begin{array}{l}\text { D. N. F. Bell } \\
\text { R. A. Hart }\end{array}$ & $\begin{array}{l}\text { How Important Is Guaranteed or Institutionalised } \\
\text { Overtime? }\end{array}$ & 5 & $04 / 03$ \\
\hline 767 & $\begin{array}{l}\text { P. Carneiro } \\
\text { K. T. Hansen } \\
\text { J. J. Heckman }\end{array}$ & $\begin{array}{l}\text { Estimating Distributions of Treatment Effects } \\
\text { with an Application to the Returns to Schooling } \\
\text { and Measurement of the Effects of Uncertainty } \\
\text { on College Choice }\end{array}$ & 6 & $04 / 03$ \\
\hline 768 & $\begin{array}{l}\text { J. J. Heckman } \\
\text { S. Navarro-Lozano }\end{array}$ & $\begin{array}{l}\text { Using Matching, Instrumental Variables and } \\
\text { Control Functions to Estimate Economic Choice } \\
\text { Models }\end{array}$ & 6 & $04 / 03$ \\
\hline 769 & $\begin{array}{l}\text { L. Flood } \\
\text { J. Hansen } \\
\text { R. Wahlberg }\end{array}$ & $\begin{array}{l}\text { Household Labor Supply and Welfare } \\
\text { Participation in Sweden }\end{array}$ & 3 & $04 / 03$ \\
\hline 770 & A. Heitmueller & Coordination Failures in Network Migration & 1 & $04 / 03$ \\
\hline 771 & $\begin{array}{l}\text { A. Calvó-Armengol } \\
\text { Y. Zenou }\end{array}$ & $\begin{array}{l}\text { Job Matching, Social Network and } \\
\text { Word-of-Mouth Communication }\end{array}$ & 5 & $05 / 03$ \\
\hline 772 & $\begin{array}{l}\text { E. Patacchini } \\
\text { Y. Zenou }\end{array}$ & $\begin{array}{l}\text { Search Intensity, Cost of Living and Local } \\
\text { Labor Markets in Britain }\end{array}$ & 3 & 05/03 \\
\hline 773 & A. Heitmueller & $\begin{array}{l}\text { Job Mobility in Britain: Are the Scots Different? } \\
\text { Evidence from the BHPS }\end{array}$ & 1 & $05 / 03$ \\
\hline 774 & $\begin{array}{l}\text { A. Constant } \\
\text { D. S. Massey }\end{array}$ & $\begin{array}{l}\text { Labor Market Segmentation and the Earnings of } \\
\text { German Guestworkers }\end{array}$ & 1 & $05 / 03$ \\
\hline 775 & $\begin{array}{l}\text { J. J. Heckman } \\
\text { L. J. Lochner } \\
\text { P. E. Todd }\end{array}$ & Fifty Years of Mincer Earnings Regressions & 5 & $05 / 03$ \\
\hline 776 & $\begin{array}{l}\text { L. Arranz-Aperte } \\
\text { A. Heshmati }\end{array}$ & $\begin{array}{l}\text { Determinants of Profit Sharing in the Finnish } \\
\text { Corporate Sector }\end{array}$ & 2 & $05 / 03$ \\
\hline
\end{tabular}

An updated list of IZA Discussion Papers is available on the center's homepage www.iza.org. 